\title{
Dialogue of Religions in the Postsecular Age: Anthropological Meanings of Islam and Christianity*
}

\author{
Olga Chistyakova \\ Faculty of Humanities and Social Sciences \\ Peoples' Friendship University of Russia \\ 6 Miklukho-Maklaya Str. \\ Moscow, Russia \\ E-mail: olgachis@yandex.ru
}

\begin{abstract}
The article is dedicated to the review of philosophical and religious ideas of the two monotheistic religions of the modern world - Christianity and Islam - from the standpoint of their leading role in establishing the interreligious dialogue and cooperation for the sake of peace. Special attention is paid to the anthropological teachings of the two religions. The author analyzes the Patristic sources of Christianity and the traditional theology of Islam, focusing on the spiritual and ideological unity of philosophical and anthropological views of these religions.
\end{abstract}

Keywords-interreligious interaction; anthropology of Islam and Christianity; individual in religions; theology

\section{INTRODUCTION}

Russia, just like many other Western countries in recent decades, is witnessing the post-secularization trends in the social and cultural spheres. However, simultaneously with the secularization processes, there are completely opposite tendencies. Forming social institutions, communities and groups don't necessarily exclude existence and actualization of theology, religious diversity and the desire of modern people to looks for religious self-identity along with the ethnic, civil or political.

In philosophical terms, secularity is a different view of piety, of the role of a creed for contemporary society. Indeed, no secular or postsecular society can underestimate the significance of religion for a modern person. In today's diversity of existential matrixes, religion becomes one of the sources of self-identity, and in this sense, it offers an individual the idea of the Other. The Other - is a person of a different culture, ethnicity, social environment and understanding of God. In the religious worldview, the Other for an individual is God.

This article spotlights the anthropological essence of Christianity and Islam in terms of their anthropological significance in the complexity of the globalizing world.

*The publication has been prepared with the support of the "RUDN University Program 5-100",

\section{Dialogue OF Religions In Postsecular AGE}

Since communications in a globalizing world have the cross-cultural character, they will always manifest connotations and differences, dissimilarity, the distinction among people of different cultures, the possibility of their rejection and discrepancy. However, religion as such in the philosophical sense, due to its anthropological essence and spiritual communicative capabilities may overcome the alienation of one person from another, one community from many others.

The dialogue of cultures is urgent today. The appeal to the sacred spiritual and rational grounds of every nation is required in connection with the growing number of conflicts and the deepening of mutual misunderstanding. Rationality, deaf to sacrilege, is unable to enter an inter-cultural dialogue. Meanwhile, factors of destructivity and irrationality strengthen. In the contemporary world, that seems to be on the civilized way of development, improving political and legal institutions to prevent violence, there is also a second tendency of the growing number of conflict outbreaks and the distribution of violence.

The French philosopher René Girard, known for creating the mimetic theory of religions, emphasizes the dual nature of the development of the modern world, where there is less violence than before, but at the same time, there is a recorded sharp increase in violence and threats of its usage. R. Girard writes: "Two opposing trends have been evolving simultaneously for many centuries with the ever-growing gap between them. Our world is saving more lives than any other world before it, simultaneously creating more victims than any other world before. The $20^{\text {th }}$ century was marked with not only the largest wars in the human history but also with concentration camps, genocides and nuclear weapon. And every day we face new and increasingly frightening threats" [1].

However, the religious ideas have now become the center of ideological speculations: the politicians are trying to manipulate the religious views of people in conformist purposes, the so-called religious leaders and missionaries use the religious senses as a "bait" to broaden the economic fields of their actions, the representatives of the so-called 
political elites often direct religious and ethnic affiliations against other ethnic groups, thus causing conflicts and extremism, terror groups often use false religious ideas to justify their inhumane activities. Misinterpreted religious ideas, used for such narrow utilitarian purposes contribute to the possibilities of manipulation of public consciousness by the means of creed.

Obviously, the problem is not in the religions itself, but in the people, using religions for their purposes. The Church, in the highest sacred meaning, could never be political. No actions "in the name of God" can be violent, destructive, let alone terror - this is the spiritual power of any Church and any religion. Religion, in whose name people are being killed, is not a religion [2]. We must combat the monstrous acts of murder in the name of religions - and the religions have priority here. To combat various kinds of social violence, there should not exist an official separation of the Church and the state, but there should be interaction and dialogue of various religious organizations and denominations.

According to the author of this article, the philosophicalanthropological teaching, inherent to any monotheistic religions, may serve as the basis for interreligious interaction. Religion in the philosophical sense deals with a person in a holistic perspective, not only in soteriology but also in the immediate earthly existence. Therefore, the integrity of an individual is a subject of rational comprehension for theology.

Religion broadcasts to society the sacred information and in this sense, establishes a specific interaction of a person with God. Justification of an individual's desire to reach God in such religions as Christianity and Islam has always caused an appropriate philosophical-anthropological reflection with the development of moral principles and concepts for the achievement of the highest goals of cognition of the absolute. The scholars of Christianity and Islam have developed a comprehensive moral doctrine using the philosophical reflexive ability and logical-categorical apparatus. Such concepts as compassion, grace, pity, sympathy, mutual understanding, and love have been derived as a priority in these moral-conceptual studies. Yet the dominant in the relationship of Self (a human) and God in both religions are the existential feelings of love and compassion. The relationship between Self and God inevitably produces moral norms and values that determine not only the cognitive attitude of an individual towards God but also the interaction among people in the communities and groups. Let us add that in the "Self - God" relationship there always will be certain moral dominants, acting as specific communicators, spiritual intermediaries, transmitting to society absolute morality and high imperatives of behavior. If this specific communication is established and demanded in society, then in the latter there is a spiritual balance of morality and culture.

Christianity and Islam share some of the religiousphilosophical ideas, having not only theocentric but also a pronounced anthropological nature [3]. These considerations relate to the relations among subject, God, and the world with a holistic conceptual understanding of the place of a human as the crown of the divine creation in the earthly universe and the rationale for the eschatological prospects of life.

\section{ANTHROPOLOGICAL MEANINGS OF CHRISTIANITY AND ISLAM}

The history of religions, inseparable from the history of cultures, presents us with great writings that speak to us, the people of the $21^{\text {st }}$ century, and question us about what is happening today. Each true work of art has a deep "hidden voice", the voice of the text. Such depth, value, and meanings, in our opinion, are found in the Patristic heritage of Christianity, outlining the relationship between a Personality and God.

If we crack open the voice of the Greek-Byzantine Patristic works of the $4^{\text {th }}-7^{\text {th }}$ centuries, then we will see, that the essence of these works lies in anthropology. Until now, the Patristic writings have been evaluated only in terms of their theological content, but the philosophicalanthropological meaning of the teachings of the Holy Fathers is still concealed from us, not manifested in the contemporary culture. These texts are rational in their essence, as they show how to combine the social sphere with the anthropological, secular sphere with the theological one. The texts from the depths of history open the way, the middle ground between religion and reason, faith and unbelief, as described by J. Habermas, who was an unbeliever.

Incredibly important for Christianity soteriological doctrine outlines the way to salvation for the eternal spiritual life in the divine world. In other worlds, soteriology speaks of a person's earthly life, illuminating the way, leading to God, provided that certain moral imperatives and spiritual practices (for cloisterers) are fulfilled. Christian anthropology explains the duality of human nature, which takes an individual from the Creator if he abuses the freedom of choice and rejects the idea of deification. The ideas of Christianity about the essence of a human as the image of God, receiving divine grace for the doing of good and noble deeds, for the cognition of the higher values, are largely similar to the Islamic theology, concerning its arguments about the place of a person in the Universe.

In Islam, a person, as a beautiful model of divine design, is also dual in the essence, being a combination of light and darkness, good and evil, also choosing his own path according to the freedom, initially given to him by Allah. In the traditional Islamic theology (Kalam) the purpose of a human's creation is described as the creation of God's vicar on the Earth. God created the "institution" of vicariate to exalt people and to make them the pinnacle of the creation. Yet every person should be a sincere and obedient servant of God, the Creator. This qualitative attitude of an individual (Self) to God is expressed by the Arabic word $A b d$, which equivalent is hard to find in other languages. In fact, $A b d$ is an attribute of Ubudiyyah - a concept, describing the essence of human superiority over all living beings but at the same time being a servant and a worshipper to Allah. 
The unique concept of Ibadah means the quest for a meeting with God, the possibility of unity with Him. Here again, we can see some connection with the Christian vision of a person, trying to comprehend God in various ways to feel the spiritual communion with the Creator. In the Christian theology, this applies to the way of deification, i.e. to the perception of the best divine qualities that allow at the deathbed or during the life (depending on the concepts, describing the methods of the cognition of God - from the conceptual theological gnosis to Hesychasm, etc.) to enter the state of religious unity with God, to feel the involvement to the divine life. It is important to note that in both religions an individual bears responsibility for choosing the way of life and for the "eternal refuge" after the death, to which he or she has been deliberately moving throughout the whole mortal life.

However, the anthropology of Islam provides differences with Christianity in understanding the concepts of asceticism and monasticism. There is no monasticism in Islam in the Christian form. The concept of Ibadah interprets asceticism as a constant worship to Allah and a strive of a Muslim to achieve the highest spiritual position, which determines the relationship between the Creator and a person. The ideals of Ibadah show that asceticism in Islam doesn't necessarily mean leaving the social world for the sake of living in another, spiritual world as a hermit. On the contrary, a Muslim shall lead a social life, but wherever he is, he should remember to worship and serve God, to fulfill the will of the Creator, to follow the rituals, and then the all-embracing faith and love for God will help to reach the heights of Ibadah.

The rather difficult religious concept of Ubudiyyah and the psychologically loaded practice of Ibadah are no less easy than the Christian ideas of asceticism and monasticism, allowing to constantly feel the presence of God (the Other) in the life of every follower of Islam. At the same time, the main goal of a Muslim is to achieve a special spiritual level, when God, who was once the Other, enter a believer's life when a person feels the presence of God as the Self.

It is interesting to trace some concepts of monasticism and asceticism in the history of Christianity in terms of comparison with the Islamic idea of asceticism since the early Byzantine era. The Christian culture of that time not only created the new spiritual ideals (e.g. martyrdom, ascetic hermitage, heroism), bringing a person closer to Christ but also outlined the ways of individual existence, following which the believers can reach the top of virtuous life and spiritual unity with God.

To establish the relationship with God, a person should learn how to control feelings, body (in Hesychasm, e.g.), to abandon material goods in the name of the spiritual benefits, to possess virtues, patience, be able to give his life for Christian ideals. In fact, the general cultural norms and individual means of the cognition of God, and unity of Self and the Other (God, who is simultaneously inherently inaccessible but also phenomenally cognizable) were substantiated. God becomes closer to a person, and, according to the concepts of the divine light (Symeon the
New Theologian, Gregory Palamas), literally "comes" to a virtuous Christian ascetic subject, following the moral, psychological, and practical imperatives. At the same time, the feeling of belonging to God was described as a phenomenon of the visitation of Jesus Christ to an ascetic monk in the ray of a special divine light [4].

Monastic ideals were an intellectual reflection of the spiritual culture of the era. In this regard, Saint John Climacus" "The Ladder of Divine Ascent" ( $6^{\text {th }}$ century $)$ is an exemplary work, which holds concentrated monastic and secular ideals. The work of Saint John Climacus substantiated thirty steps of ascension to God, starting with the idea of renunciation of the world, of all things mundane, sensual, material. The ascetic specifics were in a peculiar, conscious activity of a monk to overcome the negative aspects of worldly life (the so-called "tacit prayer").

The ascetic style of "tacit prayer", expressed in the subject's intense psychological activity, should lead to dispassion as the top of the Ladder and the top of the cognition of God. The paradox of the Easter Christian asceticism consisted in the fact that complete dispassion was achieved by the means of feeling - love, that served as the criterion of absolute spirituality of a human, restoration of unity of "the image of God", harmony of body and soul, culmination of the mystical elevation [5].

With the Christian ascetic concept of "love", a moral paradigm entered culture, according to which in this state exactly every person can find the perfection, but for this purpose, the unity of human nature must be realized.

Love for one's neighbor brings a person closer to God, allows Self to connect to the absolute Other. In the highest concept of love, a subject is practically united with God. Saint John Climacus wrote: "Love in its quality is the liking to God, people can achieve" [6]. This means the mystical (i.e., deeply personal) communication between subject and God at a constant understanding of the differences between the human Self and the infinity of God. Saint John Climacus even described love to a human as a criterion of achievement of love to God. Without loving a person, you can't love God and achieve unity with Him in the divine light. The highest step of "the Ladder" meant the transformation of a human, his essence.

The Islamic concepts of Ubudiyyah and Ibadah, with all the differences with the Christian ideas of austerity and monasticism, have something fundamentally common, namely, the desire for spiritual unity of an individual with God basing on the developed specific practices that must be performed by a Christian or a Muslim who deliberately seeks to comprehend the Absolution. In Christianity, the highest unity of a human and God is achievable through many ways, including the aforementioned mystic-ascetic, apophatic, cataphatic, symbolic-figurative cognition through art, etc. The Islamic theology for the named ascension to God has developed "ninety-nine beautiful names of Allah", directly correlating God to a human life. These names may be a sort of intermediary between the God-cognizing subject and Allah Himself. There the human Self is linked to the Other through gnoseological categories that a Muslim should 
comprehend during his life. The Islamic theology (Kalam) and the Islamic Gnosticism (Sufism) reveal the significance of these names through Allah's relation to the world and to the individual human life [7].

Thus, the similarity of Islam with Christianity is manifested in the way, elevating a human to God, which is dual and depends largely on a person himself, his selfimprovement, self-cognition, virtuous life in accordance with religious principles, but also on mercy and grace of God (and we're not specifying the name of God). The life goals of a Muslim and a Christian in their value and cognitive basis are the same - to achieve a state of mutual communication with God, to comprehend the perfect names of Allah, or moral, spiritual values-steps that separate a Christian from God ("The Ladder of Divine Ascent"), to make God's absolute characteristics "their own", internal, personal, helping in everyday work and long-term prospects. If in some degree, a person succeeds to fulfill a spiritual goal, then God, independent of religious interpretation (Allah, ar-Rahman, the Holy Trinity, the Son of God Jesus Christ), becomes the center of personal Self. Diverse religious paths assume the same goal - the spiritual and moral ascension to the unity of Self and God through the attainment of high values and religious transcendental experience.

\section{CONCLUSION}

Thus, philosophical and anthropological ideas of Christianity and Islam in their reflection on the purpose of a human, his cognitive abilities [8], moral self-improvement, and spiritual relationship with the Creator may be viewed as interreligious and intercultural, as they establish universal values and meanings, and are capable of uniting people of different ethnic cultures and religious identities.

Anthropological ideas permeate all ages and become essential to understanding and reflecting the human existence his relationship with the other people, God, and the state. In this consideration, the philosophical-anthropological values become inter-civilizational, connecting people of all ages and cultures. They were and will always be significant regardless of religious affiliation, territory, social temporality, and the forms of the government. Exactly the values of culture, religion, and spiritual life strengthen countries and peoples in the contradictory conditions of globalization.

\section{REFERENCES}

[1] René, Girard, Violence and Religion: Cause or Effect? // Logos. No. 4(67) 2008, p. 137

[2] O.V. Chistyakova. Violence and Religion as Social Phenomena of Contemporaneity (Philosophical Anthropological Context) // RUDN Journal of Philosophy. Series Philosophy. 2015, No. 1, pp. 116-136.

[3] M. Al-Janabi, N. Kirabaev, Areas of the Competence of Reason in the Teachings of Al-Ghazali // Proceedings of the 2017 2rd International Conference on Contemporary Education, Social Sciences and Humanities. (ICCESSH 2017). Advances in Social Science, Education and Humanities Research. Moscow, Russia. 14-15, June 2017. - Paris: Atlantis Press, 2017, p. 43

[4] Symeon the New Theologian, Creations. Vol. 3. Hymns of Divine Love. - Sergiev Posad. Holy Trinity St. Sergius Lavra. 1993. - P. 280.
[5] O.V. Chistyakova, Postmodernism, Christian Patristics, and Values of Peace in the Modern Cultures. (In the Context of Educational Process). // Proceedings of the 2016 International Conference on Arts, Design and Contemporary Education. (ICADCE 2016). Advances in Social Science, Education and Humanities Research. Paris: Atlantis Press, 2016. Volume 64. P. 994-999.

[6] Saint John Climacus, The Ladder of Divine Ascent. - Sergiev Posad, 1908, p. 146.

[7] N.S. Kirabaev, Philosophy in the context of classical Arab Muslim culture: issues of ideas and categories // RUDN Journal of Philosophy. Series Philosophy. 2012, No. 4, pp. 111-122.

[8] M.B. Oseledchik, V.Yu.Ivlev, M.L.Ivleva, The fractal nature of implicit knowledge // Proceedings of the 3-rd International Conference on Arts, Design, and Contemporary Education. (ICADCE 2017). Advances in Social Science, Education and Humanities Research. Paris: Atlantis Press, 2017. Vol.144, pp. 673-676. 